\title{
Academic-industry partnerships 2013
}

\section{Brady Huggett}

Public-private partnerships shrank to 301 deals in 2013, down one-fifth from the year prior. Cancer again predominated ( 84 deals), with neurology (35 deals) and infectious disease (34 deals) second and third in the rankings (Fig. 1). Harvard University was the most active deal maker (Table 1), but both Johns Hopkins University and KU Leuven broke into the top 5 in 2013. AstraZeneca was the most active pharmaceutical firm (14 deals), whereas GlaxoSmithKline fell from its zenith of 14 deals in 2012 to just 9 last year (Fig. 2).

\section{Table 1 Academic-private partnerships 2013}

\begin{tabular}{|c|c|c|c|}
\hline University & Partners & Focus & Terms \\
\hline \multirow[t]{7}{*}{ Harvard (7 deals) } & Genia Technologies, Columbia University & Genomics & \$5.3 million, US National Human Genome Research Institute grant for nanoTag sequencing \\
\hline & Evotec & Infectious & Develop small molecule inhibitors of peptidoglycan biosynthesis. Evotec holds drug rights \\
\hline & Ipsen Group & Neurology & $\begin{array}{l}\text { Undisclosed upfront payments, plus potential milestones, royalties to Harvard for recombinant } \\
\text { botulinum toxins in neurology diseases }\end{array}$ \\
\hline & Evotec & ALS & Partnership with Harvard Stem Cell Institute for preventing or slowing motor neuron loss \\
\hline & Evotec & Endocrine/Metabolic & Partnership to identify enteroendocrine mechanisms for diabetes therapies \\
\hline & Army's Edgewood Chemical Biological Center & Microfluidics & Partnership to advance organ-on-a-chip research \\
\hline & AstraZeneca & ADMET & $\begin{array}{l}\text { Deal with Wyss Institute for Biologically Inspired Engineering for animal-cell versions of insti- } \\
\text { tute's organs-on-chips }\end{array}$ \\
\hline \multirow[t]{7}{*}{$\begin{array}{l}\text { University of California } \\
\text { System ( } 7 \text { deals) }\end{array}$} & $\begin{array}{l}\text { UC Davis, Autism Speaks, Baylor College of } \\
\text { Medicine, Boston Children's Hospital }\end{array}$ & Autism & Academic groups join Austism Speaks' Preclinical Autism Consortium for Therapeutics \\
\hline & UCSF, Genetic Alliance, InVitae & Breast Cancer & Formed Free the Data! initiative, to deposit genetic data on breast cancer in databases \\
\hline & UCLA, NanoSmart Pharmaceuticals & Cancer & Deal on NanoSmart's drug delivery platform for cancer, other pediatric diseases \\
\hline & UCSF, Onyx Pharmaceuticals & Cancer & Formed the Oncology Innovation Alliance to investigate hematologic cancers, solid tumors \\
\hline & UCSF, Pfizer & Disease agnostic & Expanded 2010 partnership to include small molecules. UCSF eligible for milestones, royalties \\
\hline & UCSF, NeoStem & $\begin{array}{l}\text { Diabetes; asthma; } \\
\text { organ transplant } \\
\text { rejection }\end{array}$ & $\begin{array}{l}\text { Company's expanded 'Tregs' to be tested for diabetes, allo-specific Tregs for organ transplant } \\
\text { tolerance. UCSF could receive milestones, royalties }\end{array}$ \\
\hline & UCLA, QR Pharma & Nerve damage & $\$ 3$ million, US Army grant to test company's Posiphen in rats for traumatic brain injury \\
\hline \multirow[t]{5}{*}{$\begin{array}{l}\text { Johns Hopkins } \\
\text { University ( } 5 \text { deals) }\end{array}$} & Advanced Cell Diagnostics & $\begin{array}{l}\text { Cancer (head and } \\
\text { neck) }\end{array}$ & Deal with Sidney Kimmel Comprehensive Cancer Center to use company's RNAscope platform \\
\hline & Aduro BioTech & Cancer (melanoma) & $\begin{array}{l}\text { Combine Aduro's vaccine technologies with school's non-human anti-programmed cell death } 1 \\
\text { ligand }\end{array}$ \\
\hline & Gen9 & Genomics & Company's BioFab platform will be used in the university's Synthetic Yeast Project Sc2.0 \\
\hline & BioHealth Innovation, Dreamlt Ventures & Startups & $\begin{array}{l}\text { Launched Dreamlt Health Baltimore. } 10 \text { health IT startups will receive up to } \$ 50,000 \text { for an } 8 \% \\
\text { equity stake }\end{array}$ \\
\hline & AstraZeneca's Medimmune Project & Pharmaceuticals & Five-year, $\$ 6.5$ million deal using Medlmmune’s biologics, AstraZeneca's small molecules \\
\hline \multirow[t]{3}{*}{ KU Leuven (3 deals) } & FIT Biotech Oyj & Cancer, Infectious & Partnership to develop immunotherapies based on FIT Biotech's gene transport unit technology \\
\hline & Wellcome Trust, Janssen/Johnson \& Johnson & Infectious & Partnership to discover and develop antivirals for dengue virus \\
\hline & Johnson \& Johnson & Neurology & $\begin{array}{l}\text { Launched Stellar, a five-year collaboration on diagnostics, therapeutics for neurodegenerative } \\
\text { diseases }\end{array}$ \\
\hline \multirow[t]{3}{*}{$\begin{array}{l}\text { University of Texas } \\
\text { System ( } 3 \text { deals) }\end{array}$} & $\begin{array}{l}\text { GlaxoSmithKline, Gustave Roussy, Memorial } \\
\text { Sloan-Kettering Cancer Center, Netherlands } \\
\text { Cancer Institute, Princess Margaret Cancer Center, } \\
\text { University of Texas MD Anderson Cancer Center, Vall } \\
\text { d'Hebron Institute of Oncology }\end{array}$ & Cancer & $\begin{array}{l}\text { Group formed the Oncology Clinical and Translational Consortium (OCTC) to investigate GSK's } \\
\text { early stage cancer pipeline }\end{array}$ \\
\hline & $\begin{array}{l}\text { Illumina, Intel, Oregon Health \& Science University, } \\
\text { Leukemia \& Lymphoma Society, Stanford } \\
\text { University, University of Texas Southwestern Medical } \\
\text { Center, University of Utah }\end{array}$ & Cancer & The society committed more than $\$ 8.2$ million to the Beat AML cancer research initiative \\
\hline & $\begin{array}{l}\text { University of Texas MD Anderson Cancer Center, } \\
\text { Amorfix Life Sciences }\end{array}$ & Cancer & Parties formed deal to research misfolded proteins and identify targets for lung cancer drugs \\
\hline
\end{tabular}

Baylor College of Medicine, McGill University, Stanford, University of Montreal, Vanderbilt University: three deals apiece. Source: SciBx: Science-Business eXchange

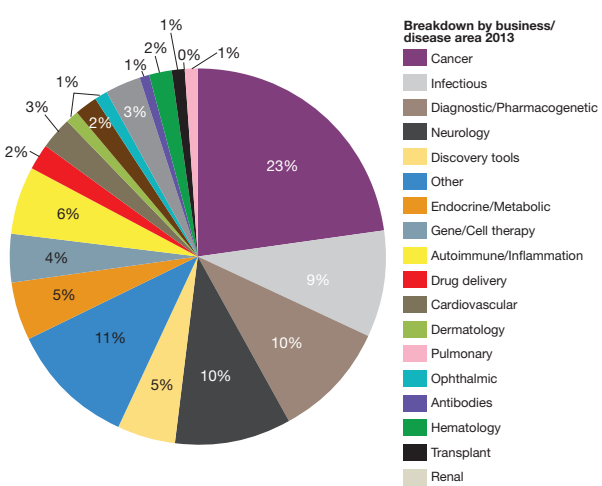

Figure 1 Deals by business area, 2013. Percentages rounded. Source: SciBx: ScienceBusiness eXchange

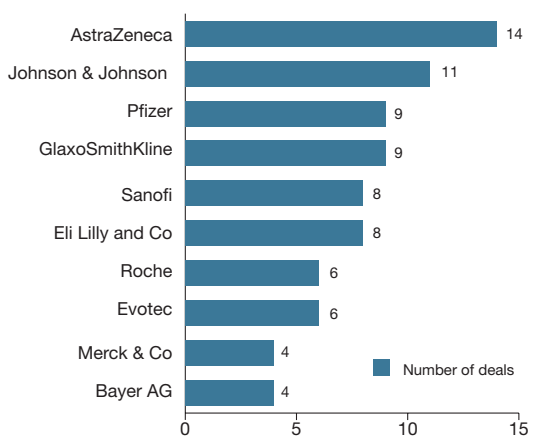

Figure 2 Most active pharmas, 2013. Takeda also had four deals. Source: SciBX: ScienceBusiness eXchange
First Rounders Podcast: Michael West

West was the first CEO for Geron, which he founded in 1990. He was also CEO of Advanced Cell Technology and is now CEO of BioTime. Nature Biotechnology talked to him about his initial love for physics, scoring the first funding for Geron and the future of regenerative medicine. http://www.nature.com/nbt/podcast/index.html

Brady Huggett is Business Editor, Nature Biotechnology 